\title{
Refleksi Putusan Bebas Kasus Korupsi dan Illegal Logging dalam Perspektif Hak-hak Azasi Manusia
}

\author{
Rusli Muhammad \\ Universitas Islam Indonesia, Yogyakarta
}

\begin{abstract}
Court decisions releasing the accused both in the cases of corruption and those of illegal logging could be influenced by juridical factor, for example the regulation on the criteria for decisions releasing the accused. This regulation would be a guide for judges. Besides, court decisions releasing the accused could also be influenced by non-juridical factor, such as return fee payment. The implication of such decisions on human rights is that the conducts of corruption and illegal logging tend to decrease and destruct the economic life, safety, peace, and welfare of people. The ideal judge decisions should be combination of normative, philosophical, and sociological considerations. These could be done by highly integrated, professional, progressive and knowledgeable judges who believe in God.
\end{abstract}

Keywords: Court Decisions, Corruption, Human Rights, Illegal logging,

Release

$\mathrm{B}$ angsa Indonesia sebagai bangsa ber Tuhan sejak semula merasakan betapa pentingnya keadilan di alam merdeka sehingga adalah wajar ketika para pendiri negara sepakat meletakkan keadilan sebagai cita-cita perjuangan bangsa yang harus diwujudkan dalam tatanan kehidupan masyarakat. Pada mula dirancangkannya era pembangunan, cita-cita perjuangan bangsa inipun dijadikan sebagai salah satu dari tujuan pembangunan itu, yakni mewujudkan suatu masyarakat adil dan makmur yang merata material dan spiritual berdasarkan Pancasila.

Rangkaian program pembangunan nasional sebagai kebijakan sosial (Social Policy) yang dijalankan terus menerus, selain dimaksudkan untuk mewujudkan

suatu masyarakat adil dan makmur, dimaksudkan pula mewujudkan tujuan nasional sebagaimana termaktub dalam Pembukaan Undang-Undang Dasar 1945, yakni melindungi segenap bangsa Indonesia dan seluruh tumpah darah Indonesia dan untuk memajukan kesejahteraan umum, mencerdaskan kehidupan bangsa dan ikut melaksanakan ketertiban dunia yang berdasarkan kemerdekaan, perdamaian abadi dan keadilan sosial.

Meskipun program pembangunan telah diusahakan sedemikian rupa namun dalam usaha mencapai masyarakat sejahtera dan adil tidak selamanya berjalan lancar. Hambatan-hambatan dan rongrongan senantiasa mengancam usaha tersebut. Berbagai macam kejahatan yang terjadi, 
korupsi misalnya, adalah salah satu bentuk hambatan dan rongrongan yang menakutkan. Dapat dikatakan bahwa hampir pada semua sektor kehidupan dan pada semua tingkatan birokrasi tidak luput dari kejahatan kerah putih ini dan sudah menempati derajat ketinggian yang membahayakan dan telah menggerogoti sekian banyak keuangan negara serta merusak proses pembangunan bangsa, bahkan telah merusak dan meruntuhkan sendi-sendi perekonomian negara.

Tidak kalah bahayanya dengan korupsi, negara ini pun terancam dengan maraknya illegal logging. Sungguh menyedihkan, sejak dihembuskannya di sektor kehutanan angkanya melonjak tajam dan semakin menggila. Hasil hutan yang menjadi asset negara dirampok oleh rakyatnya sendiri didukung petinggi-petinggi yang turut menikmati hasilnya, Sedihnya lagi kayukayu jati yang bernilai tinggi dan memakan waktu lama untuk tumbuh, dalam sekejap berubah menjadi seonggok log yang terapung tak berdaya di sisi sungai, siap diselundupkan ke luar negeri dengan harga yang sangat rendah, sungguh keterlaluan!

Adanya berbagai bentuk hambatan dan rongrongan kejahatan yang merugikan rakyat dan negara, nampaknya dihadapkan pada adanya keharusan perlindungan, baik perlindungan terhadap usaha-usaha mensejahterakan masyarakat maupun perlindungan terhadap masyarakat (Social defence) itu sendiri. Apabila hal ini terabaikan, maka dengan sendirinya citacita untuk mewujudkan kesejahteraan rakyat dan keadilan sosial akan sulit tercapai, bahkan akan terjadi sebaliknya kejahatan akan meningkat, masyarakatpun akan bertambah gelisah dan kacau.

Kebijakan perlindungan masyarakat (Social Defence Policy) dapat diwujudkan melalui usaha-usaha penanggulangan kejahatan sampai pada akar-akarnya. Selama ini berbagai bentuk reaksi dan respon sosial dapat dilakukan untuk menanggulangi kejahatan yaitu dengan cara penegakan hukum pidana/penal. Sebenarnya penanggulangan kejahatan dengan menggunakan hukum pidana/penal bukanlah satu-satunya cara, melainkan dapat pula dengan menggunakan cara atau kebijakan lain yang sifatnya non-penal, misalnya melalui jalur pendidikan, penyantunan sosial, peningkatan taraf kesehatan masyarakat dan lain-lainnya. Adanya jalur non-penal ini karena dianggap bahwa penggunaan hukum pidana atau penegakan hukum pidana bukan satu-satunya cara yang ampuh dalam menang-gulangi kejahatan. Hal ini wajar karena pada hakikatnya kejahatan itu merupakan "masalah kemanusiaan" dan "masalah sosial" yang tidak dapat diatasi semata-mata dengan hukum pidana (Muladi dan Nawawi, 1986).

Menetapkan kebijakan non-penal dalam usaha penanggulangan kejahatan adalah suatu isyarat bahwa penegakan hukum pidana dalam rangka penanggulangan kejahatan itu, kemampuannya terbatas dan bukan satu-satunya tumpuan harapan. Meskipun demikian penegakan hukum pidana tetap merupakan prioritas utama yang keberhasilannya tetap diharapkan, lagi pula pada bidang penegakan hukum inilah dipertaruhkan makna "negara berdasarkan atas hukum."'(Muladi dan Nawawi, 1986)

Penggunaan hukum pidana dalam proses peradilan, pada hakikatnya merupakan penegakan hukum pidana itu sendiri, dan ini merupakan pula bagian dari politik kriminal yaitu suatu kebijakan yang rasional guna penanggulangan kejahatan dengan tujuan akhirnya adalah kesejahteraan umat manusia.

Sebagai realisasi penggunaan hukum pidana dimunculkan berbagai peraturan 
Refleksi Putsuan Bebas Kasus Korupsi dan Illegal Logging..., Rusli Muhammad

perundang-undangan yang mengatur berbagai bentuk ragam kejahatan. Hubungannya dengan penanggulangan kejahatan korupsi telah cukup banyak undang-undang yang dibuat untuk itu hingga dibuat Undang-Undang Nomor 31 tahun 1999 yang kemudian diubah dengan Undang-Undang No 21 tahun 2001. Dalam undang-undang ini telah dirumuskan beberapa pasal yang menentukan bentukbentuk perbuatan yang dikualifikasikan sebagai perbuatan korupsi yang diancam dengan pidana . Misalnya terdapat dalam Pasal 2:

"Setiap orang yang secara melawan hukum melakukan perbuatan memperkaya diri sendiri atau orang lain atau suatu korporasi yang dapat merugikan keuangan negara atau perekonomian negara, dipidana dengan pidana penjara seumur hidup atau pidana penjara paling singkat 4 (empat) tahun dan paling lama 20 (dua puluh) tahun dan denda paling sedikit Rp 200.000.000.00 (dua ratus juta rupiah) dan paling banyak $R p$ 1.000.000.000,00 (satu milyar rupiah).

Demikian pula dalam upaya penanggulangan illegal logging telah dikeluarkan pula Undang-Undang Nomor 41 tahun 1999 tentang Kehutanan. Undang-undang ini telah menentukan berbagai perbuatan yang diancam dengan pidana. Seperti antara lain ditentukan "Setiap orang dilarang membakar hutan (Pasal 50 ayat (3) sub d); menebang pohon atau memanen atau memungut hasil hutan di dalam hutan tanpa memiliki hak atau izin dari pejabat yang berwenang (Pasal 50 ayat (3) sub e); menerima, membeli atau menjual , menerima tukar, menerima titipan, menyimpan, atau memiliki hasil hutan yang diketahui atau patut diketahui berasal dari kawasan hutan yang diambil atau dipungut secara tidak sah (Pasal 50 ayat (3) sub f). Masing-masing perbuatan tersebut diancam dengan pidana penjara dan denda (Pasal 78 ayat (4), (5) dan (6).

Ketentuan hukum pidana yang dirumuskan dalam pasal seperti tersebut di atas, sifatnya masih abstrak dan tidak dapat beroperasi dengan sendirinya. Agar dapat beroperasi dan terlihat lebih kongkrit, rumusan-rumusan abstrak tersebut memerlukan tangan-tangan yang mampu menerapkannya sehingga apa yang menjadi tujuannya dapat tercapai. Salah satu tangan yang dimaksudkan itu adalah tangan-tangan para hakim yang sebelumnya telah diberi kewenangan oleh undang-undang untuk menjalankan tugas tersebut.

Melalui interaksi dan hubungan yang serasi antara hakim dengan berbagai undang-undang korupsi dan undang-undang Kehutanan, diharapkan menjadi perisai dan pengendali meningkatnya tindak pidana korupsi dan illegal logging tersebut. Memahami hal demikian menjadikan undang-undang dengan segala perangkatnya termasuk dan terutama hakim, diperankan dalam kapasitasnya masingmasing sebagai sarana kontrol untuk mencegah dan memperkecil angka-angka atas perbuatan-perbuatan yang tergolong korupsi dan illegal logging.

Sekalipun ada rambu undang-undang dan hakim yang siap menghukumnya, namun pada realitasnya, perbuatanperbuatan yang tergolong korupsi dan illegal logging itu, ternyata tetap saja memperlihatkan dan menyebarkan aroma yang semakin menyengat. Kualitas dan kuantitasnya cenderung meningkat terbukti dengan semakin banyaknya kasus-kasus yang ditangani oleh aparat penegak hukum, baik di tingkat kepolisian, kejaksaan maupun yang telah diajukan ke pengadilan. Pengungkapan kejahatan sebanyakbanyaknya adalah suatu prestasi tersendiri namun tidak ada artinya jika hanya sekedar 
pengungapan tanpa ada penyelesaian yang berdampak preventif (pencegahan) dan represif (penjarahan).

Hakim yang menjadi aktor dalam menerapkan ketentuan hukum di pengadilan telah banyak dan berulangkali menjatuhkan palunya memberi putusan terhadap perkara korupsi dan illegal logging yang dihadapinya. Khusus untuk perkara korupsi, menurut catatan Indonesian Corruption Watch (ICW) sebagaimana disampaikan Emerson Yuntho dalam siaran persnya menyebutkan, kasus korupsi yang ditangani pengadilan sepanjang tahun 2006 mencapai 125 perkara yang telah diperiksa dan divonis. ${ }^{3}$ Sementara itu kasus illegal logging semenjak adanya reformasi di bidang kehutanan tidak henti-hentinya pula menjadi urusan hakim di pengadilan.

Reformasi yang bergulir di Indoensia pada tahun 1998, memberikan nuansa yang kondusif dan membuka koridor bagi penegakan hukum dan hak asasi manusia, sayang kondisi ini hanya dirasakan diawal-awal reformasi, itu pun terbatas pada semangat pada gemarnya memproduksi peraturan perundang-undangan, implemen-tasinya belum menyentuh cita-cita reformasi itu sendiri. Jika amanat reformasi untuk memberantas KKN dan menciptakan Pemerintahan yang bersih, nampaknya masih menjadi cita-cita yang tetap dan harus diperjuangkan.

Korupsi dan illegal logging adalah dua bentuk kejahatan yang dapat merusak sistem perekonomian dan keuangan negara secara meluas. Menurut Romli Atmasasmita : Tindak pidana korupsi yang meluas dan sistematis juga merupakan pelanggaran terhadap hak-hak ekonomi dan sosial masyarakat. (Atmasasmita, 2002) (Lihat pula Penjelasan Undang-Undang No. 20 Tahun 2001 tentang Pemberantasan Tindak Pidana Korupsi). Ini berarti bahwa tindak pidana korupsi demikian pula illegal logging merupakan pelangaran HAM karena praktek korupsi itu jelas sangat merugikan kepentingan ekonomi dan sosial masyarakat baik dalam bentuk individu maupun kelompok. Sementara I Putu Getgel mengatakan tindak pidana korupsi itu adalah perbauatan melanggar hak ekonomi dan sosial, yang merupakan bagian dari Hak Asasi Manusia.(Getgel, 2000)

Berangkat dari latar belakang tersebut di atas, maka tulisan ini dengan menempatkan judul "Refleksi Putusan Bebas kasus Korupsi dan Illegal Logging Dalam Perspektif Hak Asasi Manusia", maka dalam pembahasannya dikembangkan beberapa pokok masalah. Pertama; mencoba memahami apa faktor-faktor yang mempengaruhi terjadinya putusan bebas. Kedua; memberikan gambaran bagaimana refleksi putusan bebas terhadap kasus korupsi dan illegal logging. Ketiga; mencoba mengajukan gagasan bagaimana putusan hakim yang ideal. Ketiga pokok masalah tersebut akan diuraikan secara berurutan pada bagian di bawah ini.

\section{Faktor-faktor Pengaruh Putusan bebas}

Pengadilan melalui aktornya yakni hakim bertugas menerima, memeriksa dan menjatuhkan putusan terhadap setiap perkara yang diajukan kepadanya. Terhadap perkara yang tergolong tindak pidana, hakim tidak selamanya menjatuhkan putusuan pidana terhadap pelakunya melainkan dapat menjatuhkan putusan berupa putusan lepas dari segala tuntutan, bahkan dapat berupa putusan bebas dari segala dakwaan. Hakim sesuai dengan ketentuan undang-undang berwenang menentukan jenis putusan yang dapat diberikan kepada terdakwa, tentu dengan dasar pertimbangan-pertimbangan yang jelas, tepat, dan rasional. 
Refleksi Putsuan Bebas Kasus Korupsi dan Illegal Logging..., Rusli Muhammad

Terjadinya suatu proses perkara pidana melalui aktivitas di kepolisian diteruskan ke kejaksaan hingga sampai ke pengadilan dan berakhir hingga memperoleh putusan yang berkekuatan tetap. Logika rasionalnya, bahwa setiap perkara yang telah disaring, diperiksa dan diproses secara teliti di kepolisian dan kejaksaan hingga sampai ke pengadilan, mestinya dengan perspektif yang sama, hakim akan bersikap sama dengan pejabat sebelumnya yang menghendaki pelakunya diperiksa dan dijatuhi hukuman. Namun kenyataan tidak demikian, hakim terkadang mengambil sikap berbeda dengan menjatuhkan putusan bebas yang sangat jauh dan tidak terpikirkan sebelumnya oleh Penyidik apalagi Penuntut Umum .

Mencermati putusan bebas dalam kasus korupsi dan illegal logging yang terjadi selama ini, dapat dikemukakan bahwa terdapat dua faktor yang menyebabkan munculnya putusan bebas tersebut yakni faktor yang bersifat yuridis dan faktor yang bersifat non-yuridis. ${ }^{1}$ Faktor yang bersifat yuridis harus menjadi pilihan hakim karena hal itu memang dikehendaki oleh peraturan perundang-undangan, Alasan tersebut misalnya, ditemukan dalam Pasal 191 ayat (1) KUHAP yang berbunyi:

"Jika pengadilan berpendapat bahwa dari hasil pemeriksaan di sidang, kesalahan terdakwa atas perbuatan yang didakwaan tidak terbukti secara sah dan meyakinkan, maka terdakwa diputus bebas".

Inti alasan putusan bebas tersebut adalah karena tidak terbuktinya dakwaan jaksa penuntut umum. Ukuran terbukti tidaknya suatu perbuatan yang didakwakan dapat dilihat dari terpenuhinya alat-alat bukti minimum, dan adanya keyakinan hakim terhadap alat-alat bukti tersebut serta terpenuhi atau tidaknya unsur-unsur dari perbuatan pidana itu. Bukti minimum artinya harus tersedianya minimal 2 (dua) alat bukti dari 5 (lima) alat bukti yang ditentukan oleh Undang-Undang.

Perkembangan pemikiran hukum yang berbasis sosiologis dan Hak-Hak Manusia tidak memungkiri digunakannya faktor-faktor non-yuridis sebagai bahan pertimbangan di dalam menjatuhkan putusan. Persoalannya adalah apakah semua faktor non-yuridis dapat menjadi alasan menjatuhkannya putusan bebas itu ? tentu ada batasannya sehingga yang dapat ditolerir hanyalah terhadap hal-hal yang didukung dan mempunyai alasan pembenar berdasarkan perspektif keilmuan hukum dan hak Asasi manusia, sementara faktor-faktor non-yuridis yang muncul dari nafsu serakah, kotor dan bersifat mafia seharusnya tidak diberi tempat dan harus dijauhi.

Dalam perspektif HAM setiap individu memiliki hak-hak menikmati kebebasan hidup dan berhak mendapatkan perlakuan yang sama di depan hukum. Menurut G. Robertson Q.C yang dikutip oleh Mahsyur Effendi bahwa:

"Tak seorang pun boleh disiksa atau diperlakukan atau dihukum secara keji, tidak manusiawi, atau merendahkan martabat. Setiap orang berhak atas penyelesaian yang efektif oleh

1 Faktor yuridis dimaksudkan adalah faktor-faktor yang telah ditentukan dan terdapat dalam suatu peraturan perundang-undangan, dalam hal muncul di persidangan akan menjadi alasan dan sandaran bagi hakim untuk menjatuhkan putusan bebas. Sementara yang dimaksud faktor non-yuridis adalah faktor-faktor di luar ketentuan perundangundangan yang muncul di dalam atau di luar persidangan, baik atas inisiatif pelaku kejahatan maupun dari diri hakim sendiri dan dapat berdimensi ilmu pengetahuan, politik, ekonomi atau pun kemanusiaan. 
UNISIA, Vol. XXX No. 64 Juni 2007

peradilan nasional untuk mendapatkan perlindungan yang sama terhadap tindakan-tindakan yang melanggar hak-hak mendasar yang diberikan kepadanya oleh konstitusi atau hukum"

Pembatasan atau perampasan terhadap hak individu dapat ditolerir hanya dengan undang-undang dan dengan mengimplementasikan hak-hak asasi manusia. Oleh karena itu apapun putusan yang dijatuhkan oleh hakim termasuk putusan bebas terhadap terdakwa dapat dibenarkan asalkan melalui ukuran undangundang dengan mekanisme yang jujur, transparan dan manusiawi. Peradilan yang jujur, transparan dan manusiawi oleh Suparman Marzuki dianggapnya sebagai Hak Asasi Manusia, sebagaimana terbaca pada salah satu judul tulisannya yakni "Peradilan yang fair, transparan dan manusiawi adalah hak asasi manusia" judul ini kemudian menjadi tesis utama tulisannya itu.

Diakui bahwa dalam prakteknya terdapat putusan bebas yang dilandasi oleh faktor non-yuridis berdasarkan alasan pembenar menurut perspektif keilmuan hukum dan Hak Asasi Manusia, namun tidak dipungkiri pula bahwa sekian banyak putusan bebas dalam kasus korupsi dan illegal logging yang dipengaruhi oleh faktorfaktor non-yuridis di luar perspektif keilmuan dan HAM melainkan perspektif komersial kotor dengan cara tawar menawar perkara dan putusannya dengan standar dan ukuran "uang sebagai jasa".

Praktek mafia peradilan rasanya sulit dibasmi karena begitu rusaknya moral para penegak hukum. Jaksa penuntut umum, penasihat hukum dan hakim bermain dengan hukum, mereka sepertinya menjalankan tugas mulia, mereka dalam penampilan dan gaya terlihat sungguh-sungguh melakukan pemeriksaan baik kepada saksi maupun kepada terdakwa, namun yang dilakukan sesungguhnya adalah permainan busuk, mereka telah menghianati keadilan dan kebenaran hakim dengan penampilan yang meyakinkan sepintas telah memperlihatkan kepada publik, pengunjung persidangan bahwa ia telah melakukan persidangan dengan penuh tanggung jawab, namun dibalik persidangan itu telah terjadi pemufakatan jahat di antara mereka dengan "uang jasa". Uang jasa inilah sebagai salah satu wujud terpopuler faktor non-yuridis dan yang paling sering menjadi lahirnya putusan bebas.

Sri Bintang Pamungkas dalam bukunya memberikan perincian tentang tarif uang jasa ini. Disebutkan bahwa, untuk kasus-kasus umum, seperti pencurian, pembobolan, perampokan dan pembunuhan mempunyai kelas tersendiri: Kelas di bawah 50 juta rupiah, kelas antara 50 hingga 100 juta, atau kelas di atas 100 juta dan seterusnya. Untuk kasus-kasus seperti pembunuhan, :uang jasa"yang terlibat bisa mencapai di atas 100 juta rupiah. Sedang untuk kejahatan ekonomi, seperti membobol bank lewat komputer dan penggelapan pajak, "uang jasa"nya bisa mencapai milyaran rupiah.

\section{Refleksi Putusan bebas kasus Korupsi dan Illegal Logging}

Undang-undang telah memberikan kewenangan kepada hakim untuk memeriksa, mengadili dan menjatuhkan putusan terhadap terdakwa di sidang pengadilan. Hakim memiliki kebebasan dalam menjalankan kewenangan itu, kebebasan hakim dijamin oleh undangundang sehingga tidak ada satu kekuasaan manapun yang dapat mencampuri urusan 
Refleksi Putsuan Bebas Kasus Korupsi dan Illegal Logging..., Rusli Muhammad

pengadilan itu. Jadi pada dasarnya dalam/ untuk memeriksa dan mengadili, hakim bebas untuk menentukan sendiri cara-cara memeriksa dan mengadili. Kebebasan hakim merupakan asas yang sifatnya universal, yang terdapat dimana saja dan kapan saja. Asas ini berarti bahwa dalam melaksanakan peradilan, hakim itu pada dasarnya bebas, yaitu bebas dalam/untuk memeriksa dan mengadili perkara dan bebas dari campur tangan atau turun tangan kekuasaan ekstra yudisiil.

Sekalipun kebebasan ini dimiliki oleh para hakim, namun kebebasan ini bukan tanpa batas melainkan dibatasi oleh hukum dan keadilan masyarakat. Khusus tentang kebebasan, budayawan (Mangunwidjojo 1997) mengartikan kebebasan sebagai tepo seliro (Jawa) tahu diri, saling ada tenggang rasa dan saling menghormati. Dikatakan selanjutnya: .. kebebasan yang dimiliki manusia adalah kebebasan untuk berbuat kebajikan. Karena, manusia makhluk yang mempunyai tanggung jawab.

Kebebasan hakim harus dihargai, akan tetapi seorang hakim harus pula melaksanakan kebebasan itu dengan penuh tanggung jawab dengan memperhatikan kaedah (norma) dan ajaran-ajaran hukum dan perkembangannya serta nilai-nilai kemanusiaan dalam masyarakat. Dengan pemahaman demikian karya-karya yang dihasilkan oleh hakim melalui putusannya akan berdaya guna bagi kehidupan manusia. Akan tetapi jika kebebasan itu disalahgunakan, sebaliknya akan berdampak buruk bagi kehidupan umat manusia.

Putusan bebas pada kasus-kasus korupsi dan illegal logging dari hari ke hari masih tetap mewarnai dunia peradilan. Berbagai kasus korupsi dan illegal logging yang diajukan ke pengadilan berakhir dengan putusan bebas, kalau dengan pidana penjara, cenderung jauh dengan tuntutan pidana yang diajukan oleh penuntut umum apalagi dengan yang dirumuskan dalam undang-undang.

Sebagai gambaran dari 125 kasus korupsi, sebanyak 40 perkara dengan 117 terdakwa divonis bebas oleh pengadilan karena dianggap tidak bersalah, sedangkan yang divonis dengan hukuman di bawah dua tahun penjara sebanyak 37 perkara, jauh lebih banyak dibandingkan dengan perkara yang divonis di atas dua tahun hingga lima tahun yakni sebanyak 32 perkara. Sementara pada kasus illegal logging ditemukan pula adanya putusan bebas seperti di pengadilan Negeri Papua telah menjatuhkan putusan bebas terhadap 14 kasus, Demikian pula di PN Tanjung yang menjatuhkan putusan bebas terhadap terdakwa (Suara Karya, 2007).

Refleksi putusan bebas terhadap kasus korupsi dan illegal logging akan berdampak buruk bagi usaha-usaha penanggulangan kejahatan dalam segala bentuknya, khususnya tindak pidana korupsi dan illegal logging. Dengan putusan bebas itu menjadikan para pelaku-pelaku potensial tergerak untuk meneruskan niatnya melakukan perbautan korupsi dan illegal logging tersebut. Sementara pecandupecandu yang telah terbiasa melakukan berbuatan yang terkutuk itu akan termotifasi terus untuk mengulanginya lagi.

Ini berarti tingkat kejahatan korupsi dan illegal logging tidak pernah akan berhenti melainkan tetap melaju hingga tingkat yang membahayakan. Akibatnya kerugian di sektor keuangan dan perekonomian negara menjadi meningkat. Berkenaan dengan kerugian ini, Ketua badan Pengawasan Keuangan dan Pembangunan (BPKP) Arie Soelendro memaparkan bahwa kerugian negara akibat tindak pidana korupsi selama tahun 2004 hingga April 2005 sebesar Rp 
3,551 triliun dan US\$ 74,6 juta atau Rp 716,2 miliar (dengan kurs Rp 9.600 per 1 US \$ (Tempo, 2005).

Kerugian negara akibat korupsi di atas, tambah diperburuk dengan menjamurnya illegal logging. Berdasarkan pers release dari Departemen Kehutanan pada tanggal 15 Januari 2003 bahwa, kayu-kayu yang diselundupkan dari Kalimantan, Papua, Sumatera Utara, Riau dan Nanggroe Aceh Darussalam (NAD) mencapai 10 juta meter kubik per tahun, sedangkan penebangan dan peredaran kayu secara liar dalam negeri mencapai 50,7 juta meter kubik per-tahun, dengan perkiraan kerugian yang ditanggung negara sebesar Rp 30.42 triliun per tahun. (Nurjana dkk, 2005)

Sementara itu mendurut Menteri Kehutanan, H.M.S. Kaban mengungakpkan bahwa dampak adanya illegal logging ternyata telah mengakibatkan kerugian negara Rp 30 triliun pertahun dan kerusakan hutan di Indonesia seluas 2,8 juta ha per tahun dengan kerugian mencapai Rp 40 triliun per tahun. Dari 120 juta ha luas hutan, yang mengalami kerusakan sekitar 56 juta hektar. Menurutnya, Illegal logging yang paling besar terjadi di luar Pulau Jawa, yaitu Papua, Sumatra, dan Kalimantan. Sementara di Jawa Tengah dan Jawa barat frekuensinya kecil. ${ }^{14}$ Lebih lanjut Kaban mengatakan, hutan di Indonesia ibarat orang yang terkena penyakit kanker yang ada pada stadium empat. Jika dibiarkan terus terjadi, kondisinya hanya bisa bertahan lima belas tahun lagi.

Gejala banjir yang setiap musim hujan selalui menghantui beberapa pemukiman penduduk di berbagai perkotaan. Banjir yang terjadi baru-baru ini di Jakarta sungguh menyengsarakan penduduk karena tidak saja menimbulkan kerugian materiil yang cukup banyak, tapi lebih mengerikan adalah mengancam nyawa mereka karena genangan air ada mencapai 2 meter bahkan lebih. Menurut analisa ilmiah, banjir tersebut akibat dari tidak ada atau berkurangnya hutan yang dapat menampung air hujan, kebanyakan sudah menjadi tempat pemukiman atau dijarah untuk keuntungan pribadi.

Demikian pula banjir bandang yang terjadi di Kecamatan Panti, Kabupaten Jember yang mengakibatkan lebih 80 nyawa melayang disebabkan illegal logging. Bahkan, akibat proses penggundulan dan konservasi hutan tanpa pertimbangan dimensi ekologis yang rasional, mengakibatkan negara merugi Rp 220 milyar. Praktik illegal logging di daerah penghasil tembakau terbaik di Jatim itu berlangsung sejak tahun 1999 dan mencapai puncaknya pada tahun 2002. Illegal logging ini bisa berlangsung aman dan lancar akibat kongsi bisnis antara cukong kayu dan aparat birokrasi pemerintah serta beking oknum petugas keamanan. (Suripto, 2006)

Gambaran akibat kejahatan korupsi dan illegal logging tersebut di atas adalah suatu angka yang menakjubkan dan jika tidak dicegah, bukannya lagi meruntuhkan sendisendi perekonomian negara melainkan merembet pula pada hak-hak asasi manusia. Menurut (Masyhur Effendi, 2001) HAM meliputi hak sipil/hak politik dan hak sosial/ hak ekonomi/hak kultural yang tertuang dalam Deklarasi Hak Asasi Manusia Sedunia 10 Desember 1948, terkait dengan dihormati-nya hak berbeda pendapat, tertuang di dalam Pasal 21 Ayat 3. Ketentuan tersebut diperkuat dalam Perjanjian Internasional tentang Hak Sipil dan Hak Politik dan Perjanjian Internasional tentang Hak Ekonomi, Sosial, dan kebudayaan yang mempunyai kekuatan hukum yang mengikat dan disetujui Majelis Umum PBB tahun 1966. 
Refleksi Putsuan Bebas Kasus Korupsi dan Illegal Logging..., Rusli Muhammad

Membiarkan Korupsi dan illegal logging melalui putusan bebas berarti membiarkan uang dan kekayaan negara dirampas dan dinikmati oleh hanya segelintir orang yang bernyali bejat dan bermoral bobrok. Uang dan kekayaan negara yang dirampas itu pada hakekatnya secara tidak langsung adalah hak-hak masyarakat sebagai rakyat negara. Menurut Kamri A. uang negara yang dirampas oleh orang-orang yang tidak bertanggung jawab, secara tidak langsung pula merampas hak-hak masyarakat. Karena mereka telah merampas hak-hak masyarakat dengan cara korupsi, maka itu berarti terjadi juga pelanggaran hak asasi manusia. Sebab dalam setiap rupiah uang milik negara terdapat juga hak milik masyarakat. Lebih lanjut (Kamri, 2005) mengatakan, masyarakat di sini bukan hanya sekedar warga negara, tetapi bisa juga berarti "masyarakat dalam arti sebagai manusia yang mempunyai hak atas kekayaan perdata negara."

Adanya pelanggaran dengan merampas hak-hak rakyat menjadikan rakyat semakin tidak berdaya mendapat kesempatan memenuhi dan menikmati hak-hak asasinya. Hak untuk hidup sebagaimana diatur dalam Bagian Kesatu Pasal 9 Undang-Undang No 39 tahun 1999 menyebutkan:

(1) Setiap orang berhak untuk hidup, mempertahankan hidup dan meningkatkan taraf kehidupan.

(2) Setiap orang berhak hidup tenteram, aman, damai bahagia, sejahtera lahir dan batin.

(3) Setiap orang berhak atas lingkungan hidup yang baik dan sehat.

Hak hidup tenteram, aman, damai, bahagia, sejahtera lahir dan batin sebagaimana tersebut pada Ayat (2) di atas semakin sulit dicapai. Bagaimana bisa hidup tenteram kalau setiap musim hujan nyawa terancam oleh banjir yang terkadang tidak disangka-sangka datangnya. Bagaimana bisa hidup bahagia, sejahtera kalau perkerjaan sulit didapatkan, sementara hasil-hasil pembangunan dan pengelolaan hutan yang mestinya dapat juga merambah dalam kehidupan mereka semuanya berpindah tangan, dirampas oleh sekelompok kecil manusia bermoral bejat.

Selain hak-hak tersebut di atas, hakhak seperti pada Pasal 12 juga menjadi sebuah impian yang sulit terjangkau. Isi pasal ini menyebutkan bahwa :

"Setiap orang berhak atas perlindungan bagi pengembangan pribadinya untuk memperoleh pendidikan, mencerdaskan dirinya dan meningkatkan kualitas hidupnya agar menjadi manusia yang beriman, bertakwa, bertanggung jawab, berakhlak mulia, bahagia dan sejahtera sesuai dengan hak asasi manusia."

Pasal tersebut memberikan penekanan pada pengembangan diri melalui pendidikan. Pendidikan adalah usaha yang sadar dari setiap individu untuk mengembangkan kepribadiannya dan kemampuannya di dalam maupun di luar sekolah,sepanjang masa hidupnya. Pendidikan adalah suatu usaha yang sengaja dibuat dan direncanakan dengan tujuan mengubah perilaku manusia. (Kusuma, 1981)

Dalam pasal 26 Universal Declaration of Human Rights ayat 2 ikhwal pendidikan ini dikatakan sebagai berikut:

"Pendidikan ditujukan ke arah perkem-bangan kepribadian manusia serta untuk memperkokoh penghargaan terhadap hak-hak asasi manusia dan kebebasan-kebebasan dasar manusia. Pendidikan harus mempertinggi saling pengertian, toleransi dan persahabatan antara bangsa-bangsa, ras dan kelompokkelompok keagamaan serta 
memajukan kegiatan-kegiatan PBB dalam memelihara perda-maian."

Masyarakat Indonesia yang sebagian berada pada garis kemiskinan dan kebodohan akan tetap berada pada dunianya dan mungkin akan bertambah lebih parah dari itu. Usaha pendidikan yang dilakukan untuk mengangkat derajat kemanusiaan dan martabat diri, hanya dapat dijangkau oleh sebagian manusia yang berduit, sementara lainnya hanya berpangku tangan merenungkan nasibnya. Dampak kejahatan korupsi dan illegal logging secara tidak langsung menghasilkan kondisi demikian. Sekiranya sedikit saja terbebas dari kejahatan ini, kemungkinan besar anggaran pendidikan dengan alokasi dana $20 \%$ dari keseluruhan anggaran pendapatan dapat terpenuhi sehingga membantu meringankan biaya-biaya pendidikan yang terjangkau oleh keseluruhan rakyat.

\section{Putusan Hakim yang Ideal}

Dunia peradilan tidak pernah luput dari sorotan dan selalu menjadi obyek kajian yang hangat. Salah satu persoalan yang sering menjadi bahan perbincangan di dunia peradilan adalah menyangkut "putusan hakim" karena pada putusan inilah selain menentukan nasib seseorang juga sebagai ukuran seberapa jauh tingginya penegakan hukum dan hak-hak asasi manusia yang dilaksanakan di wilayah pengadilan.

Lahirnya suatu putusan selain melalui suatu proses yang panjang, dibutuhkan pula sumber daya dan keterlibatan pemikiran dan tenaga yang banyak ,karena hal demikian adalah kebutuhan dan tuntutan yang dikehendaki oleh peraturan perundangudangan. Hakim sebagai sentral dan penentu di sidang pengadilan dengan sendirinya akan lebih banyak berperan dan bertanggung jawab penuh dalam setiap tahapan pemeriksaan hingga melahirkan putusannya itu.

Terdapat beberapa komponen ${ }^{19}$ yang saling berintegrasi di dalam persidangan, sekalipun peranan masing-masing berbeda namun mengarah pada satu tujuan yakni menghasilkan suatu putusan yang adil berdasarkan Ketuhanan Yang Maha Esa. Proses menuju putusan adalah melibatkan seluruh komponen pengadilan, namun pengambilan putusan adalah tetap menjadi kewenangan hakim selaku pemimpin di persidangan.

Hakim telah banyak menghasilkan putusan, dan tetap akan menjatuhkan putusannya sepanjang pengadilan tetap dibanjiri perkara. Telah banyak putusan, namun dari sekian putusan hakim yang banyak itu, ada pula yang bermasalah baik yang berbentuk putusan pemidanaan lebihlebih lagi yang berbentuk putusan bebas, seperti putusan hakim dalam kasus illegal logging di Pengadilan Negeri Tanjung Balai Sumatera Utara yang dinilai bermasalah sehingga majelis hakimnya dipanggil untuk dimintai keterangan terkait dengan vonis bebas terdakwa. Bagaimanakah sesungguhnya suatu putusan hakim yang ideal itu, pertanyaan ini akan dibahas berikut ini.

Dengan berpedoman pada pasal 197 KUHAP dapat diketahui beberapa hal yang harus dimuat di dalam suatu putusan. Salah satu dari hal tersebut yang perlu mendapat perhatian adalah; "pertimbangan mengenai fakta dan keadaan beserta alat pembuktian yang diperoleh dari pemeriksaan di persidangan". Berdasarkan ketentuan ini berarti hakim dalam menyusun pertimbangan-pertimbangan putusannya terbatas pada 3 (tiga) hal yakni , fakta, keadaan, dan alat pembuktian yang diperoleh dari pemeriksaan di persidangan. 
Refleksi Putsuan Bebas Kasus Korupsi dan Illegal Logging..., Rusli Muhammad

Selain ketiga hal tersebut, berbagai hal lainnya yang dimuat dalam putusan berdasarkan pasal 197 tidak luput pula menjadi pertimbangan hakim, misalnya surat dakwaan, tuntutan pidana, pasal peraturan yang menjadi dasar pemidanaan dan dasar hukum putusan , pernyataan kesalahan dan unsur-unsur dalam tindak pidana dan lain sebagainya. Pertimbangan demikian ini dapat digolongkan sebagai pertimbangan yuridis normatif. Hasil pengamatan yang dilakukan terhadap 40 putusan dengan mengambil sampel di 4 (empat) pengadilan negeri DIY menunjukkan sebagian besar putusan tersebut, pertimbangannya lebih bersifat yuridis normatif (Muhammad, 2006).

Putusan hakim yang cenderung menggunakan pertimbangan yuridis normatif menunjukkan hakim selalu menggunakan ukuran peraturan perundang-undangan sebagai pisau dalam memecahkan persoalan. Logika berpikirnya adalah logika berpikir deduktif, yakni menempatkan aturan-aturan atau pasal hukum yang bersifat umum ke dalam kasus-kasus yang konkret. Nuansa pemikiran hakim demikian itu tidak lepas dari posisinya sebagai seorang profesional yang pandangannya senantiasa melihat dan memahami hukum sebagai peraturan (rules) yang selalu menjadi pegangannya.

Sejalan dengan profesionalisme itu, adanya pertimbangan yang bersifat yuridis normatif itu tidak luput pula dengan adanya suatu ajaran yang sudah berakar dan mendarah daging dan telah mengikat merasuk bertahun-tahun bahkan berpuluh puluh tahun pemikiran para ilmuwan hukum di tanah air sehingga sulit untuk meninggalkan ajaran yang bersifat legalistik positivistik, itulah ajaran dari Teori Hukum Normatif.

Putusan hakim yang mengandalkan pertimbangan yuridis normatif pada satu segi dapat memberi keuntungan bagi hakim sendiri, sebab hakim tidak perlu memeras pikiran dan mengeluarkan tenaga yang banyak untuk menemukan dan menyusun pertimbangannya. Fakta-fakta yang sudah ada di pengadilan sepanjang sudah memenuhi kriteria undang-undang maka itulah pertimbangannya tanpa harus berpikir panjang lagi. Namun pada segi lainnya putusan hakim yang mengandalkan pertimbangan yuridis normatif itu hanya dapat menghasilkan keadilan formal yang sangat jauh berbeda dengan kadilan substantif. Bahkan bisa terjadi lebih buruk lagi jika fakta-fakta yang terungkap di sidang pengadilan adalah fakta hasil rekayasa semata, maka tentu putusan yang dihasilkan tidak sedikit pun menyentuh keadilan baik formal maupun yang substantif.

Berbagai kasus korupsi dan illegal logging dengan mengandalkan pertimbangan yuridis normatif berakhir dengan putusan bebas, namun kemudian diketahui bahwa putusan bebas itu ternyata bermasalah atau dipermaslahkan oleh jaksa penuntut umum dengan mengajukan kasasi ke Mahkamah Agung. Masih belum lepas dari ingatan putusan bebas yang diberikan kepada Tommy Soeharto tidak diterima oleh jaksa penuntut umum kemudian mengajukan kasasi. Hakim Agung Saifuddin mengabulkan kasasi jaksa dan menghukum Tommy dengan pidana penjara, meskipun kemudian berakibat kematiannya. Demikian pula putusan bebas yang diberikan hakim kepada 14 perkara pembalakan liar di seluruh Papua yang lagi-lagi kejaksaan juga mengajukan kasasi ke Mahkamah Agung. Kasus ini pun mendapat perhatian dari Komisi Yudisial.

Untuk menyempurnakan putusan hakim, maka perlu dikembangakan tidak saja pertimbangan yuridis normatif melainkan menjangkau pada pertimbangan 
yuridis filosofis. Kebutuhan akan pertimbangan yuridis filosofis dalam rangka mencari kebenaran yang sesungguhnya yang terkadang tidak dapat ditemukan melalui logika deduktif dengan landasan undang-undang, melainkan hanya dapat ditemukan melalui logika induktif dengan landasan akal pikiran yang rasional dan hati nurani yang tulus ikhlas. Pertimbangan ini lebih mengarah pada nilai-nilai, berupa nilai kebenaran, kemanusiaan, keadilan, dan nilai ketuhanan dan sebagainya.

Tidak mudah memenuhi kebutuhan ini, hanya dapat dipenuhi dengan hakim yang terbuka pikiran dan mata hatinya. Hakim yang selalu melibatkan cipta (logos), karsa (etos) dan rasa(pathos) dalam hidup dan kehidupannya, berlaku jujur dan senantiasa khusu' memunajat kepada sang Penciptanya. Dalam hal ini mengingatkan kita pada sosok mantan Hakim Agung Bismar Siregar yang tidak selamanya menggunakan ukuran undang-undang atau norma positif dalam menyusun putusannya. Pertimbangannya terkadang melampaui apa yang dikehendaki oleh undang-undang dengan menentukan pertimbangan sendiri, menyentuh tidak saja nilai-nilai kemanusiaan melainkan nilai-nilai ketuhanan.

Selain kedua bentuk pertimbangan yuridis tersebut, putusan hakim akan lebih sempurna jika memperhatikan dan memuat pula pertimbangan yuridis sosiologis. Pertimbangan ini adalah pertimbangan hakim yang didasarkan pada suatu keadaan yang tidak diatur dalam aturan perundang-undangan, namun keadaan tersebut melekat pada diri pembuat tindak pidana atau berhubungan dengan tindak pidananya itu sendiri maupun berkaitan dengan masalah-masalah sosial dan struktur masyarakat. Pertimbangan ini dapat pula berupa fakta-fakta yang secara riil tidak terungkap di sidang pengadilan tapi fakta tersebut dapat dirasakan dan diprediksi akan keberadaannya. Suatu peristiwa dapat saja tidak terungkap di pengadilan namun tetap merupakan suatu fakta yang diakui keberadaannya karena ada di dalam pikiran dan pergaulan kehidupan masyarakat.

Pertimbangan yuridis sosiologis ini masih sangat langka menghiasi putusan hakim, tidak mudah bagi seorang hakim untuk dapat menyusun putusannya dengan syarat akan pertimbangan-pertimbangan yuridis sosiologis itu, lebih-lebih bagi hakim yang masih berpikiran konservatif dan statis menggunakan ajaran-ajaran normatif legal teori yang tergolong dalam mazhab positivistik. Untuk itu upaya mendapatkan putusan hakim dengan muatan pertimbangan yuridis sosiologis sangat dibutuhkan hakim yang progresif, yang scientifik mengikuti perkembangan masyarakat dan keilmuan di bidang hukum .

Gambaran hakim yang progresif itu selalu tidak puas dengan kebenaran formalistik, kebenaran menurut undangundang tetapi selalu mencari kebenaran subtansial, kebenaran yang diakui dalam masyarakat dilandasi oleh nilai-nilai kemanusiaan yang universal. Gambaran sebagai seorang scientifik senantiasa memperlihatkan sikapnya obyektif sehingga semua informasi ilmiah menjadi bahan pertimbangannya tanpa kecuali sekalipun bergeser dari kebiasaan atau ajaran tradisional,. Sekalipun ia berada dalam dunia profesi tapi apa yang dilakukan tidak semata-mata dalam kerangka profesionalisme tapi juga dalam kerangka keilmuan, yakni tidak semata-mata bekerja untuk membuat dan menetapkan putusan dengan melihat dan menerapkan secara bulat-bulat aturan-ataturan hukum yang bersifat abstrak melainkan ia senantiasa melihat masalah yang dihadapi dalam konteks yang lebih luas. Aturan hukum 
Refleksi Putsuan Bebas Kasus Korupsi dan Illegal Logging..., Rusli Muhammad

yang dihadapinya tidak dilihatnya sebagai sesuatu yang abstrak dan apa adanya sebagaimana yang tertulis, tetapi dilihatnya sebagai proses yang isi maupun rumusannya bisa saja berubah dari waktu ke waktu sesuai dengan kondisi masyarakat saat itu.

Pensyaratan untuk mencapai putusan hakim yang ideal, nampaknya tidak cukup dengan mengandalkan pertimbangan yuridis normatif belaka, melainkan dibutuhkan pula kombinasi dengan pertimbanganpertimbangan yuridis lainnya baik yang berupa yuridis filosofis maupun yuridis sosiologis . Kombinasi dan intetgrasi ketiga pertimbangan yuridis di dalam setiap putusan hakim diharapkan dapat menghasilkan putusan hakim yang ideal. Namun untuk mencapai hal demikian sangat ditentukan oleh kualifikasi hakim yang terbuka pikiran dan mata hatinya, hakim yang selalu melibatkan cipta (logos) , karsa (etos) dan rasa(pathos) dalam hidup dan kehidupannya, profesional, progresif scientifik berlaku jujur dan senantiasa khusu' memunajat kepada sang Penciptanya.

\section{Kesimpulan}

Berdasarkan keseluruhan dan urutanurutan uraian di atas, maka sebelum menutup tulisan ini beberapa simpulan dapat diajukan yakni sebagai berikut:

Bahwa terjadinya putusan bebas baik dalam kasus korupsi maupun illegal logging dapat dipengaruhi oleh faktor yuridis berupa ketentuan peraturan perundang-undang yang menentukan kriteria putusan bebas dan menjadi pedoman bagi hakim. Selain faktor yuridis dipengaruhi pula oleh faktor non-yuridis yang cenderung muncul dari pihak yang berperkara berupa tawar menawar perkara dengan ukuran "uang jasa".
Bahwa implikasi putusan kasus korupsi dan illegal logging dalam perspektif HAM adalah:

1. Tingkat kejahatan akan cenderung meningkat mengingat pelaku potensial akan terdorong dan termotifasi melakukan kejahatannya sementara yang mendapat putusan bebas akan ketagihan melakukan kejahatan kembali.

2. Membiarkan Korupsi dan illegal logging melalui putusan bebas berarti membiarkan uang dan kekayaan negara dirampas dan dinikmati oleh hanya segelintir orang yang bernyali bejat dan bermoral bobrok. Uang dan kekayaan negara yang dirampas itu pada hakikatnya secara tidak langsung adalah hakhak masyarakat sebagai rakyat negara, maka itu berarti terjadi juga pelanggaran hak asasi manusia. Sebab dalam setiap rupiah uang milik negara terdpat juga hak milik masyarakat.

3. Akibat korupsi dan illegal logging yang melemahkan keuangan dan merusak sendi-sendii perekonomian negara berdampak pula pada hak-hak asasi manusia. Hak hidup tenteram, aman, damai, bahagia, sejahtera lahir dan batin sebagai wujud hak-hak asasi semakin sulit dicapai. Demikian pula hak untuk pengembangan pribadinya untuk memperoleh pendidikan, mencerdaskan dirinya dan meningkatkan kualitas hidupnya yang dijamin oleh undang-undang tinggal menjadi impian belaka, hal ini seiring ketidakmampuan negara menyediakan dan mefasilitasinya disebabkan lemahnya keuangan dan perekonomian negara 
UNISIA, Vol. XXX No. 64 Juni 2007

Bahwa putusan hakim yang ideal adalah putusan yang dapat mengkombinasikan dan mengintegrasikan berbagai pertimbangan antara pertimbangan yuridis normatif dengan pertimbangan yuridis filosofis dan yuridis sosiologis. Pertimbangan demikian hanya dapat dicapai oleh hakim yang memiliki integritas tinggi , profesional, scientifik progresif dan senantiasa khsusu' memunajat kepada sang Penciptanya.

\section{Daftar Pustaka}

Muladi dan Barda Nawawi,1986. "Ruang Lingkup Penegakan Hukum Pidana dalam Konteks Politik Kriminal" (Makalah Seminar Kriminologi, FH UNDIP Semarang.

Suara Karya online 25-1-07

Romli Atmasasmita,2001. "Reformasi Hukum, Hak Asasi Manusia \& Penegakan Hukum, Bandung: Mandar Maju.
I Putu Getgel, " Harmoni Pembangunan Hukum Dalam Pemberantasan Korupsi dan Penegakan HAM di Indonesia; Sebuah Pandangan Alternatif, Dalam Muladi "Hak Asasi Manusia.

Sri Bintang Pamungkas,2001. "Dari Orde Baru ke Indonesia Baru Lewat Reformasi Total" Jakarta:Penerbit Erlangga.

Suara Merdeka Rabu 11 Januari 2006.

Kamri A, dalam Muladi (editor),2005. "Hak asasi Manusia, Hakekat, Konsep dan Implikasinya dalam Perspektif Hukum dan Masyarakat. Bandung: Tafika Aditama.

Rusli Muhammad,2006. "Potret lembaga Pengadilan Indoensia, Jakarta: Rajawali.

Mulyana W Kusuma,1981. "Hukum dan Hak-Hak Asasi Manusia, Suatu Pemahaman Kritis" Bandung: Alumni: Bandung. 